\title{
A Cellular Model of Endothelial Cell Ischemia
}

\author{
Daniel B. Hinshaw, M.D.,' Barbara C. Armstrong, B. A., \\ Theodore F. Beals, M.D., ${ }^{*}$ and Paul A. Hyslop, Ph.D. $\dagger$ \\ Departments of Surgery, Medical College of Virginia, Richmond, Virginia 23298, and University of Michigan, Ann \\ Arbor, Michigan 48105; and *Department of Pathology, University of Michigan, Ann Arbor, Michigan 48105, and \\ + Department of Immunology, Scripps Clinic and Research Foundation, La Jolla, California 92037
}

Presented at the Annual Meeting of the Association for Academic Surgery, Orlando, Florida, November 1-4, 1987

Endothelial cell dysfunction in ischemia may cause increased capillary permeability. We examined the effect of failing ATP synthesis, a major consequence of ischemia, on microfilaments-important structural determinants of the endothelial cell. Glycolytic and mitochondrial ATP synthesis in bovine pulmonary artery endothelial cells was inhibited by glucose depletion and 650 picomole (pmole) oligomycin $/ \mu \mathrm{g}$ DNA, respectively. ATP levels were monitored with the luciferase-luciferin assay over a 2-hr time course followed by recovery for $1 \mathrm{hr}$ after removal of the oligomycin and addition of 5.5 $\mathrm{m} M$ glucose. ATP levels fell to $83.6 \pm 63.8 \mathrm{pmole} / \mu \mathrm{g}$ DNA $(n=11)$ by $30 \mathrm{~min}, 26.9 \pm 13.8 \mathrm{pmole} / \mu \mathrm{g}$ DNA $(n=11)$ by $60 \mathrm{~min}$, and $17.2 \pm 3.8 \mathrm{pmole} / \mu \mathrm{g}$ DNA $(n=6)$ by $120 \mathrm{~min}$, whereas control uninjured cells had $541.3 \pm 196.8$ pmole/ $\mu \mathrm{g}$ DNA $(n=6)$ at $120 \mathrm{~min}$. Fluorescence microscopy of microfilaments stained with rhodamine-phalloidin revealed progressive disassembly and shortening of the microfilaments in $>90 \%$ of cells over 60 min which correlated with the fall in ATP. Ultrastructural examination revealed that side to side aggregation of microfilaments had occurred over the 120 -min time course. Two hours of glucose depletion $(305.5 \pm 130.8$ pmole ATP $/ \mu \mathrm{g} \mathrm{DNA}, n=6)$ or oligomycin alone $(480.0 \pm 90.1 \mathrm{pmole}$ ATP $/ \mu \mathrm{g}$ DNA, $n=6)$ failed to produce the dramatic fall in ATP or the microfilament changes. During cell recovery, there was a rapid reassembly of microfilaments, detected by fluorescence microscopy, which was nearly complete in $85-90 \%$ of cells by $45-60 \mathrm{~min}$. ATP levels increased significantly $(P=0.002)$ to $96.1 \pm 36.8 \mathrm{pmole} / \mu \mathrm{g} \mathrm{DNA}(n=6)$ by $30 \mathrm{~min}$. This model should provide insight into the pathogenesis and treatment of the capillary leak seen with ischemia. 1988 Academic Press, Inc.

\section{INTRODUCTION}

Increased capillary permeability is frequently seen in conjunction with acute ischemic tissue injury. Endothelial cell dysfunction as a result of ischemia may be an important factor mediating the changes in permeability. Inhibition of cellular ATP synthesis by depletion of substrate (e.g., glucose) and oxygen is a major biochemical consequence of acute ischemia following interruption of blood flow.

Microfilaments are important structural determinants of cells which are primarily composed of the protein actin, in its polymerized form. ATP is an important regulator of the cycling of actin within the cell between

\footnotetext{
${ }^{1}$ To whom correspondence and reprint requests should be addressed at: Surgical Service (112) V. A. Medical Center, 2215 Fuller Road, Ann Arbor, MI 48105 .
}

the monomeric $(\mathrm{G})$ and polymeric $(\mathrm{F})$ forms $[1,2]$. Cells depleted of ATP have demonstrated progressive disruption of microfilaments which was reversible [2-5].

It is unclear whether the biochemical events (i.e., inhibition of anaerobic and aerobic ATP synthesis) which are major sequelae of acute ischemia following vascular occlusion affect mammalian endothelial cell ATP levels and in turn microfilament organization.

To address this question, we examined the impact of acute glucose depletion (inhibition of glycolysis) and treatment with 650 pmole oligomycin $/ \mu \mathrm{g}$ DNA (inhibition of mitochondrial respiration) on the levels of ATP in bovine pulmonary artery endothelial cells as a model of endothelial cell ischemia. The dose of oligomycin, which interferes with electron transport as well as phosphorylation of ADP [6], was derived from previous work 
$[7,8]$. The effect of this treatment on microfilament organization in endothelial cells was then examined by fluorescence and electron microscopic techniques. The potential reversability of changes in endothelial cell microfilament organization induced by the metabolic inhibition was also examined and correlated with ATP levels in recovering cells.

\section{METHODS}

Cells and culture. Bovine pulmonary artery endothelial cells (No. AG2791A) obtained from the National Institute of Aging, Aging Cell Culture Repository (Camden, NJ) were cultured at $37^{\circ} \mathrm{C}$ under $5 \% \quad \mathrm{CO}_{2} / 95 \%$ air in medium RPMI 1640 supplemented with $2 \mathrm{~m} M$ glutamine (GIBCO), 10\% fetal bovine serum (Whittaker, M.A. Bioproducts), $10 \mathrm{~m} M$ Hepes (Whittaker, M.A. Bioproducts), $100 \mathrm{u} / \mathrm{ml}$ penicillin, and 100 $\mu \mathrm{g} / \mathrm{ml}$ streptomycin (GIBCO). Cells were grown in $150-\mathrm{cm}^{2}$ flasks (Corning) or on collagen-coated beads (Cytodex 3, Sigma) in a spinner flask (Techne, Cambridge, UK), spinning at $30 \mathrm{rpm}$. Experiments in which ATP measurements were performed were done with cells on microcarrier beads in suspension or with cells from $150-\mathrm{cm}^{2}$ flasks suspended following a brief exposure (10-15 $\min )$ to trypsin $(0.05 \%)$ and EDTA $(0.02 \%)$ (Sigma). The cells were suspended at an approx concentration of $18 \mu \mathrm{g} \mathrm{DNA} / \mathrm{ml}$ in a buffer containing $147 \mathrm{mM} \mathrm{NaCl}, 5 \mathrm{mM} \mathrm{KCl}$, $1.9 \mathrm{~m} M \mathrm{KH}_{2} \mathrm{PO}_{4}, 1.1 \mathrm{~m} M \mathrm{Na}_{2} \mathrm{HPO}_{4}, 0.3$ $\mathrm{m} M \mathrm{MgSO}_{4}, 1 \mathrm{~m} M \mathrm{MgCl}_{2}, 5.5 \mathrm{~m} M$ glucose, $10 \mathrm{~m} M$ Hepes, and $1.5 \mathrm{mM} \mathrm{CaCl} 2$. In some experiments, glucose was absent from the buffer.

Experiments with suspended cells were carried out at $37^{\circ} \mathrm{C}$ in a shaking water bath.

DNA measurements. Endothelial cell DNA content was measured using a fluorometric assay [7, 9]. Briefly, cells were sonicated for $30 \mathrm{sec}$ in a buffer containing $2 \mathrm{M}$ $\mathrm{NaCl}$ and then exposed to $1 \mu \mathrm{g} / \mathrm{ml}$ Hoechst dye No. 33258 (Calbiochem). Fluorescence measurements of DNA content were made on a Perkin-Elmer LS5 spectrofluorometer with excitation at $356 \mathrm{~nm}$ and emission at $458 \mathrm{~nm}$. Fluorescence measurements were then compared to a standard curve generated using calf thymus DNA (Boehringer-Mannheim). Comparisons between DNA content and cell number obtained from counting cell suspensions in a hemacytometer yielded a relationship of approx $1 \mu \mathrm{g} \mathrm{DNA}=10^{5}$ cells.

ATP measurements. Cellular ATP levels were measured by the luciferase-luciferin method of Stanley and Williams [10] as previously adapted for use with endothelial cells [7] with a few modifications. The luciferaseluciferin (Sigma No. L0633) was reconstituted at $40 \mu \mathrm{g} / \mathrm{ml}$ sterile water (on ice) and diluted 1:50 in a buffer which contained $1 \%$ bovine serum albumin, $20 \mathrm{~m} M$ glycine, and $2 \mathrm{~m} M$ EDTA at $\mathrm{pH}$ 8.0. The final working solution was kept on ice and made fresh every 30-45 min. A new standard curve was generated after each batch of diluted enzyme was made. Measurements were made using a Beckman (LS8000) liquid scintillation counter with the photomultiplier tube signals accepted out of coincidence.

Fluorescence microscopy. Adherent endothelial cells were grown overnight in six-well plates (Nunc) or on glass coverslips at an approx density of $1-2 \times 10^{5} \mathrm{cells} / \mathrm{cm}^{2}$. Metabolic inhibition was carried out after a wash step in which the culture media was removed and replaced with the experimental buffer. At various times throughout the time course of the experiment, adherent cells were stained with rhodamine-phalloidin, a probe specific for the polymerized or $F$ form of actin in microfilaments [11]. The staining procedure $[12,13]$ was as follows: buffer was removed from the plate and $1 \mathrm{ml}$ per well of a cocktail with final concentrations of 50 $\mu \mathrm{g} / \mathrm{ml}$ lysophosphatidyl choline, $1.85 \%$ phosphate-buffered formalin, and $165 \mathrm{n} M$ rhodamine-phalloidin in buffer was added to the cells. This was incubated for $10 \mathrm{~min}$ at $37^{\circ} \mathrm{C}$ or $20 \mathrm{~min}$ at room temperature. After removal of the excess stain solution, a glass coverslip was sealed to the monolayer in the six-well plates with $5 \mu \mathrm{l}$ of $90 \%$ glycerol, or the glass coverslips with stained cells were 
sealed with the glycerol to microscope slides. The cell monolayers were then examined for their rhodamine fluorescence staining patterns with a Nikon Optiphot fluorescence microscope. Fluorescence micrographs were taken at $400 \times$ magnification using Plus $\mathrm{X}$ film (Kodak). Fixation of cells with $2 \%$ paraformaldahyde prior to permeabilization with $1 \%$ Triton $X-100$ and staining with rhodamine-phalloidin were also used [14] and there was no difference seen in staining patterns or microfilament organization between the one-step and the two-step procedures.

Transmission electron microscopy. Adherent endothelial cells, grown in the same manner as for fluorescence microscopy, were fixed in situ with $2 \%$ glutaraldehyde at room temperature at various times after metabolic inhibition. The fixed cells were then scraped off of the plastic substrate with a rubber policeman and centrifuged. The cell pellet was embedded in albumin (which gels when exposed to glutaraldehyde). The resultant block was postfixed in $1 \% \mathrm{OsO}_{4}$ for $60 \mathrm{~min}$, and then stained en bloc with uranyl acetate for $20 \mathrm{~min}$. Samples underwent dehydration in graded concentrations of ethanol with several final passages in absolute ethanol. They were then transferred through propylene oxide into a monomer mixture (Poly/Bed 812, Polysciences, Inc., Warrington, PA; Araldite; dodecenyl succinic anhydride; and tri(dimethylaminoethyl)phenol) and polymerized at $60^{\circ} \mathrm{C}$. One-micrometer thick sections were stained with toluidine blue for review in the light microscope, and selected areas were thin sectioned at $60 \mathrm{~nm}$ and mounted on copper grids. Sections were stained with Reynold's lead citrate and uranyl acetate. Thin sections were examined in a Zeiss 9S-2 electron microscope.

\section{RESULTS}

Endothelial cell ATP. Endothelial cell ATP levels were measured to assess the metabolic impact of acute inhibition of glycolysis and mitochondrial respiration by glucose depletion and exposure to 650 pmole oligomycin $/ \mu \mathrm{g}$ DNA, respectively. Endothelial cells were inhibited metabolically for $2 \mathrm{hr}$ and then allowed to recover for $1 \mathrm{hr}$ during which

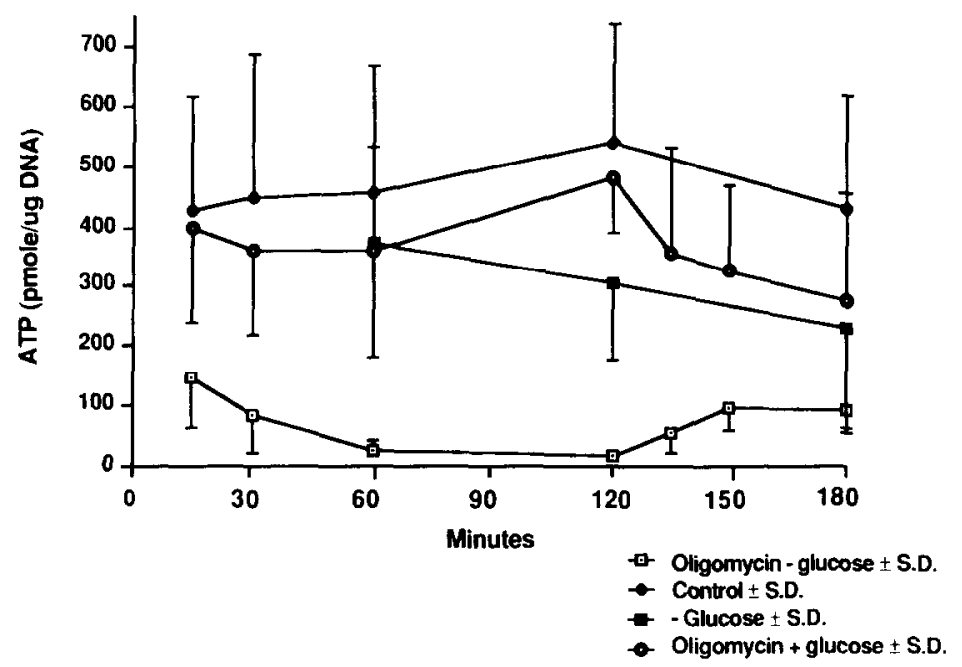

FIG. 1. Time course of ATP levels in endothelial cells exposed to buffer with glucose (solid circles), glucose plus $650 \mathrm{pmole}$ oligomycin/ $\mu$ g DNA (open circles), no glucose present (solid squares), and no glucose present plus 650 pmole oligomycin $/ \mu$ g DNA (open squares). After $120 \mathrm{~min}$, cells exposed to oligomycin were washed rapidly and $5.5 \mathrm{mM}$ glucose was added for $60 \mathrm{~min}$ of recovery. All data points represent the mean $\pm \mathrm{SD}$ of between 5 and 11 separate observations. See text for details of statistical analysis. 

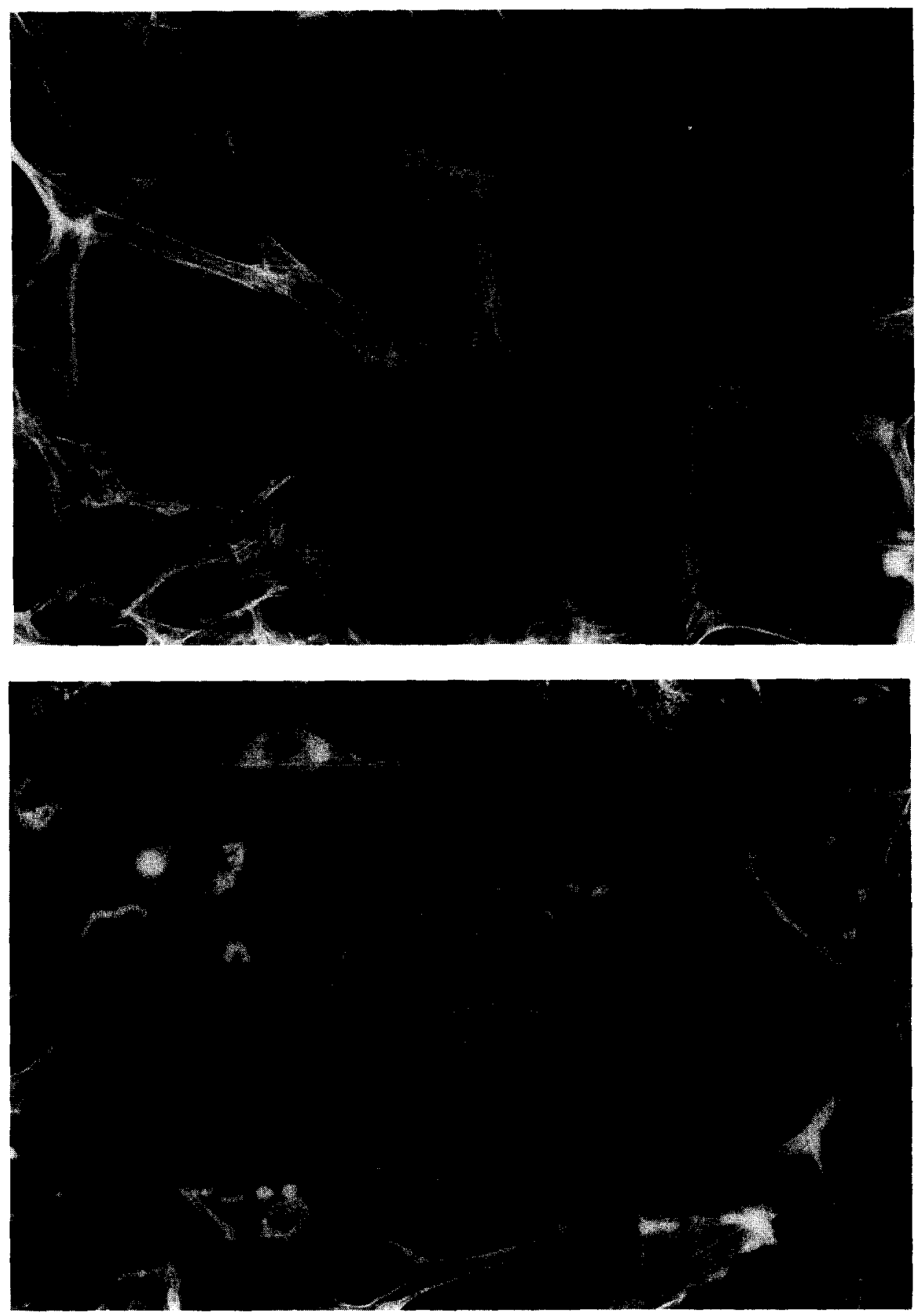

FIG. 2. Time course of changes in microfilament organization in endothelial cells exposed to 650 pmole oligomycin $/ \mu \mathrm{g}$ DNA in the absence of glucose over $60 \mathrm{~min}$. Cells were stained with rhodamine-phalloidin and viewed at $400 \times$ magnification. (A) Control ( + glucose), uninjured cells; (B) 30 min plus oligomycin in the absence of glucose; (C) $60 \mathrm{~min}$ plus oligomycin in the absence of glucose. Note the progressive shortening and apparent aggregation of microfilaments occurring over $60 \mathrm{~min}$ of metabolic inhibition. 


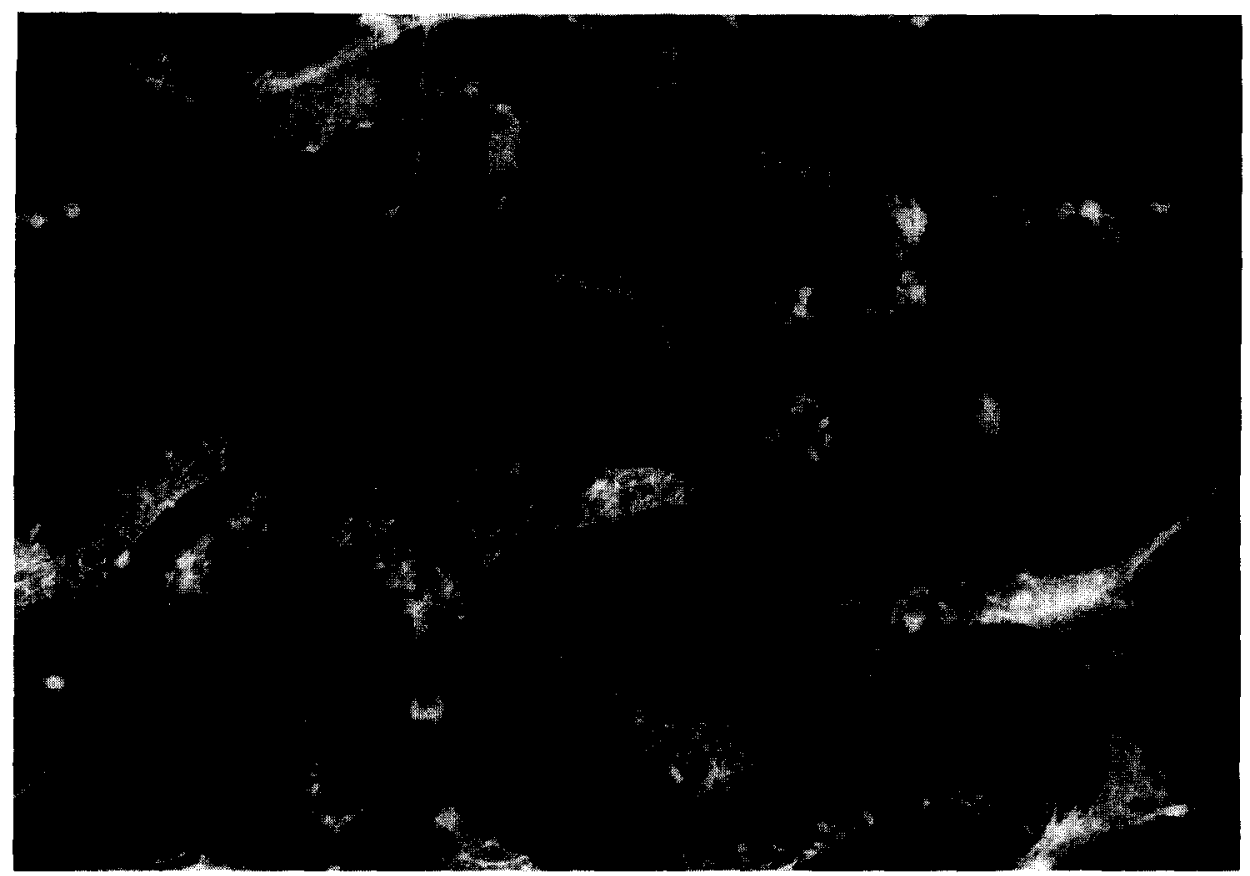

FIG. 2. (Continued)

glucose $(5.5 \mathrm{~m} M)$ was added to the buffer and oligomycin removed in a rapid wash step. The combined inhibition of glycolytic and mitochondrial ATP synthesis produced a rapid and dramatic fall in endothelial cell ATP levels (Fig. 1). Data from cells exposed to oligomycin in the absence of glucose were compared with those from cells exposed to glucose, glucose plus oligomycin, and glucose depletion over the 3-hr time course. Since there were considerable differences between the variances of the metabolically inhibited cells and the three control groups, Welch's solution to the Behrens-Fisher problem [15] was used. The three control groups were significantly different $(P$ $<0.003$ ) from the metabolically inhibited group (oligomycin in the absence of glucose) with the exception of glucose depletion alone at $180 \mathrm{~min}$, even after adjusting for multiple comparisons with Bonferroni's inequality. After $120 \mathrm{~min}$ when the inhibited cells were washed free of oligomycin and glucose (5.5 $\mathrm{m} M$ ) was restored, ATP levels increased over the following 30-60 min but not to control levels (Fig. 1). Paired $t$ tests were used to compare the levels of ATP in metabolically inhibited cells (lower curve-Fig. 1) at 120 min of inhibition and following the initiation of recovery at 135,150 , and $180 \mathrm{~min}$. The most significant difference was between 120 and $150 \mathrm{~min}$ (30 min of recovery; $P$ $=0.002$ ).

\section{Microfilament Organization-Endothelial Cells}

Fluorescence microscopy. Adherent endothelial cells were fixed and stained with rhodamine-phalloidin over the time course of metabolic inhibition depicted in Fig. 1. There was a progressive loss of normal microfilament organization in $>90 \%$ of cells over the $2 \mathrm{hr}$ of inhibition with dramatic shortening of $F$ actin into aggregates within the cells (Figs. 2 and 3). When the inhibited endothelial cells were allowed to recover after $2 \mathrm{hr}$ of metabolic inhibition, there was a rapid reassembly of microfilaments within the cells as early as 15 min after addition of 


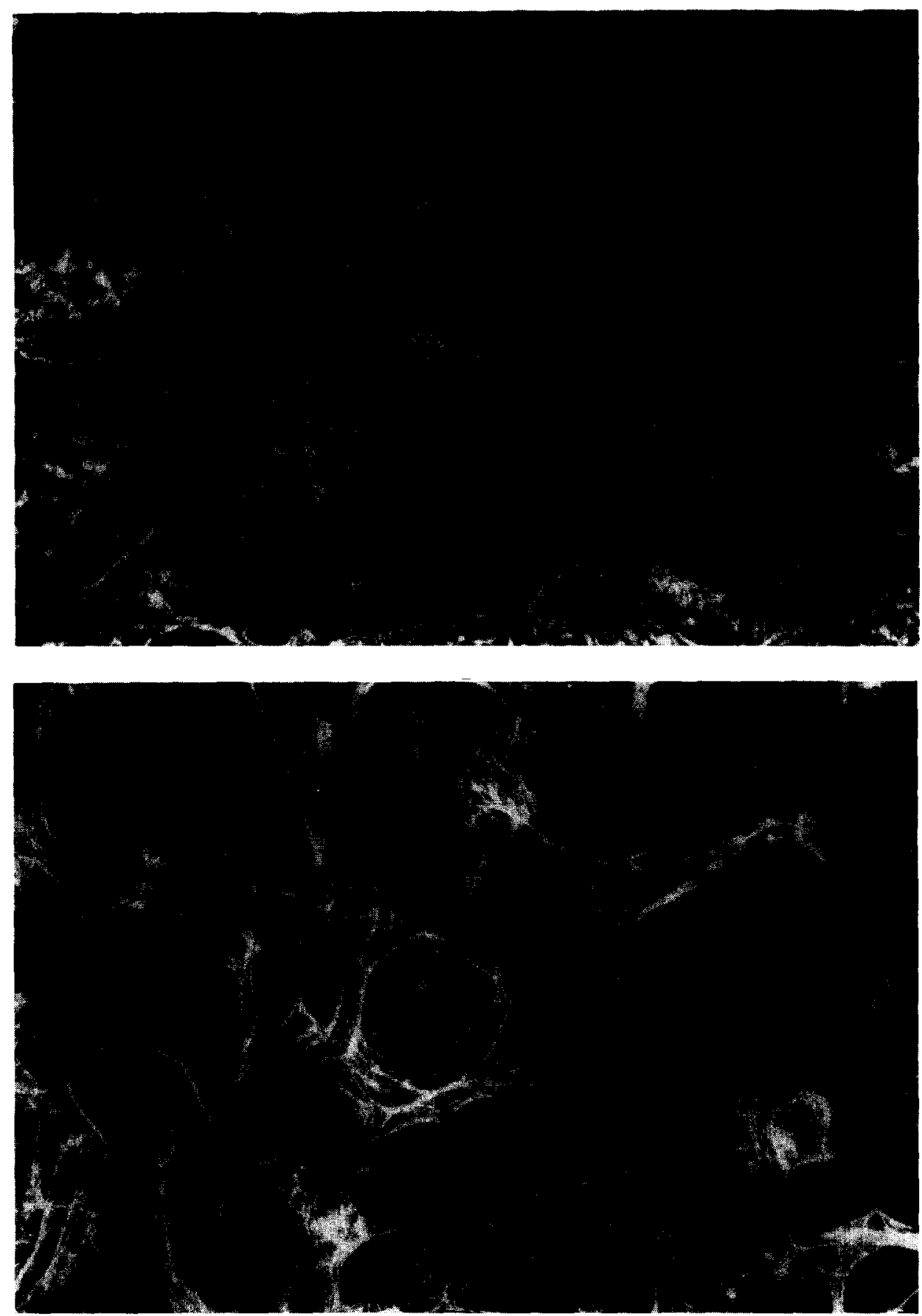

FIG. 3. Time course of changes in microfilament organization during $60 \mathrm{~min}$ of recovery after $120 \mathrm{~min}$ of metabolic inhibition with 650 pmole oligomycin $/ \mu \mathrm{g}$ DNA in the absence of glucose. Cells were stained with rhodamine-phalloidin and viewed at 400× magnification. (A) $120 \mathrm{~min}$ exposure to oligomycin in the absence of glucose; (B) $150 \mathrm{~min}$ (30 min recovery) oligomycin removed and $5.5 \mathrm{mM}$ glucose added at 120 $\mathrm{min}$; (C) $180 \mathrm{~min}$ (60 min recovery) oligomycin removed and $5.5 \mathrm{~m} M$ glucose added at $120 \mathrm{~min}$. Note the rapid return to normal microfilament architecture over $30-60 \mathrm{~min}$ of recovery. 


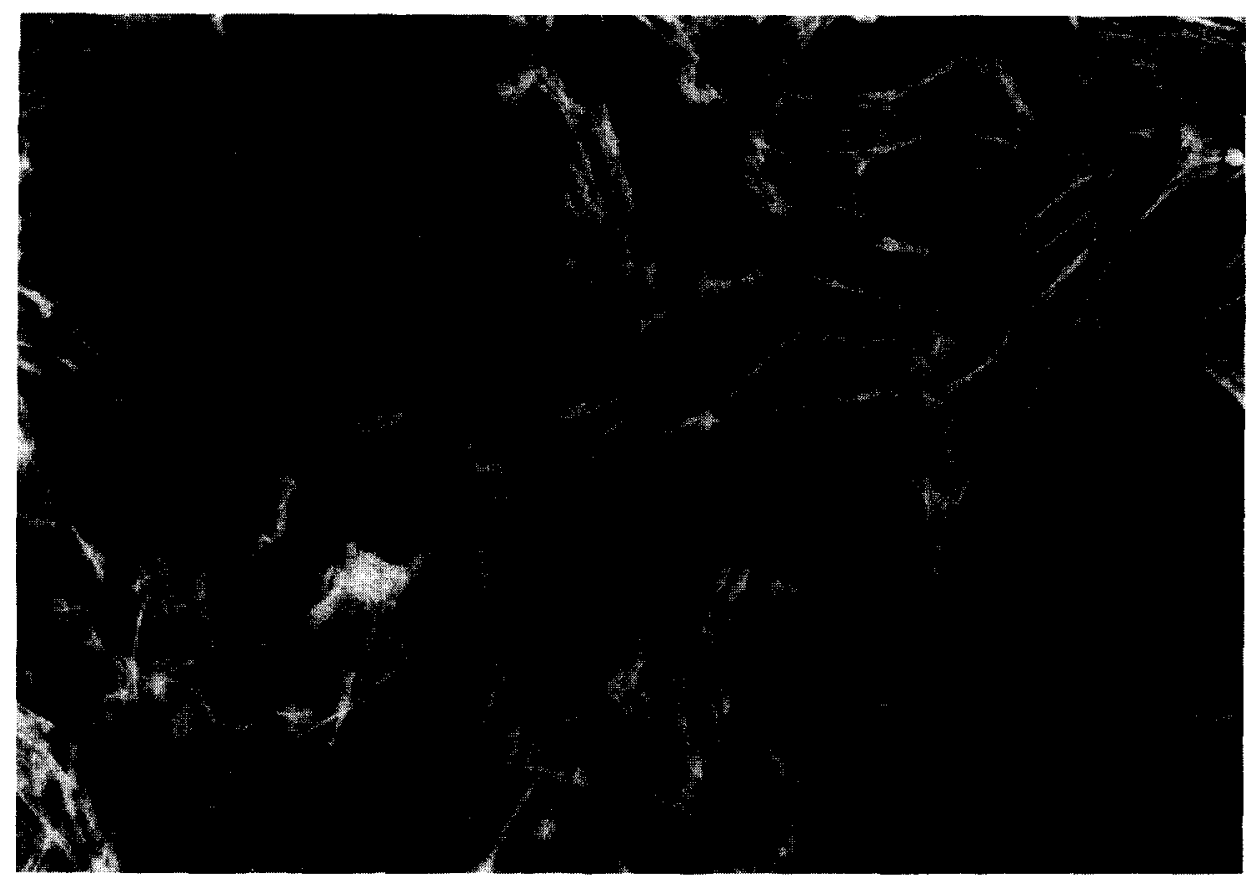

FIG. 3. (Continued)

glucose and removal of oligomycin which was nearly complete in $85-90 \%$ of cells by 60 min (Fig. 3). Inhibition of either glycolytic or mitochondrial ATP synthesis alone did not alter the pattern of microfilament organization in the endothelial cells as compared to control cells in buffer containing glucose (data not shown).

Transmission electron microscopy (EM). To further characterize ultrastructural changes in endothelial cell microfilament organization associated with inhibition of ATP synthesis, adherent cells were fixed with glutaraldehyde and prepared for transmission EM. Ultrastructural examination of metabolically inhibited endothelial cells showed a change from the diffuse distribution of cytoplasmic microfilaments to aggregation into bundles (Fig. 4). The layer of conspicuous microfilaments normally present parallel to the surface onto which the cells adhere also disappeared. As would be expected, cytoplasmic particulate glycogen disappeared under these conditions. Restoration of ATP synthesis was associated with a gradual resto- ration of the normal diffuse distribution of microfilaments within the recovering cells (Fig. 5).

\section{DISCUSSION}

To produce a rapid and sustained fall in endothelial cell ATP levels, it was necessary to inhibit both aerobic and anaerobic ATP synthesis. This kind of situation should be theoretically operative during acute ischemic events in vivo where substrate (glucose) and $\mathrm{O}_{2}$ delivery would be suddenly interrupted. ATP levels did fall in an in vivo model of renal ischemia to a range ( $<10 \%$ of controls) which was comparable to that seen in this in vitro study [16]. This indicates that in vivo ATP levels during ischemia could be affected to the same degree as seen with this in vitro model making it theoretically possible for changes in the cell cytoskeleton associated with ATP depletion to occur in vivo. The ability of the endothelial cells to maintain ATP synthesis at fairly normal levels via either glycolytic or mitochondrial pathways 

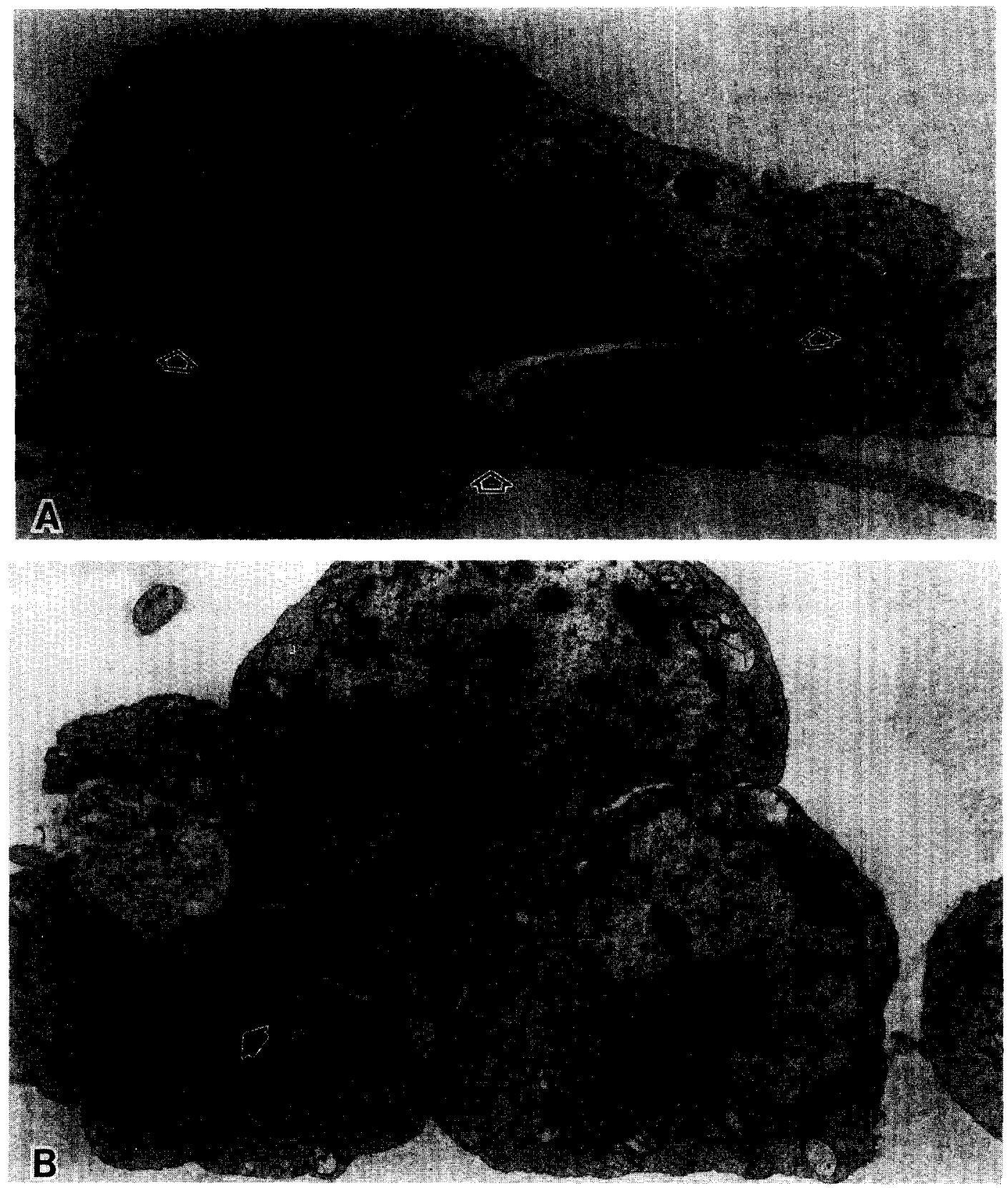

FIG. 4. Transmission electron microscopy of adherent endothelial cells at 120 min of metabolic inhibition. (A) Control-uninjured cell(s) 10,800× magnification. Normal ultrastructural pattern with microfilaments scattered throughout the cytoplasm and a normal basal layer of microfilaments (open arrows); (B) oligomycin in the absence of glucose 10,200 $\times$ magnification. Note the side to side aggregate (solid arrow) of microfilaments in the metabolically inhibited cell.

alone emphasizes their adaptability in the face of a variety of metabolic stresses. From correlation of microfilament changes seen with fluorescence microscopy to changes in ATP levels occurring over the time course of metabolic inhibition in Fig. 1, it appears that 
the approximate threshold level of endothelial cell ATP which correlates with destabilization of microfilaments occurs in the range of $15-20 \%$ of control levels (taken from data at $30 \mathrm{~min}$ of inhibition and at $60 \mathrm{~min}$ of recovery). It is quite interesting that ATP levels in recovering cells do not reach normal control levels over the 60 -min recovery pe- riod. This may represent a very rapid turnover and utilization of newly synthesized ATP in recovering cells for biosynthetic processes interrupted by the period of metabolic inhibition including reassembly of disrupted microfilaments.

The reversability of the microfilament changes associated with ATP depletion in
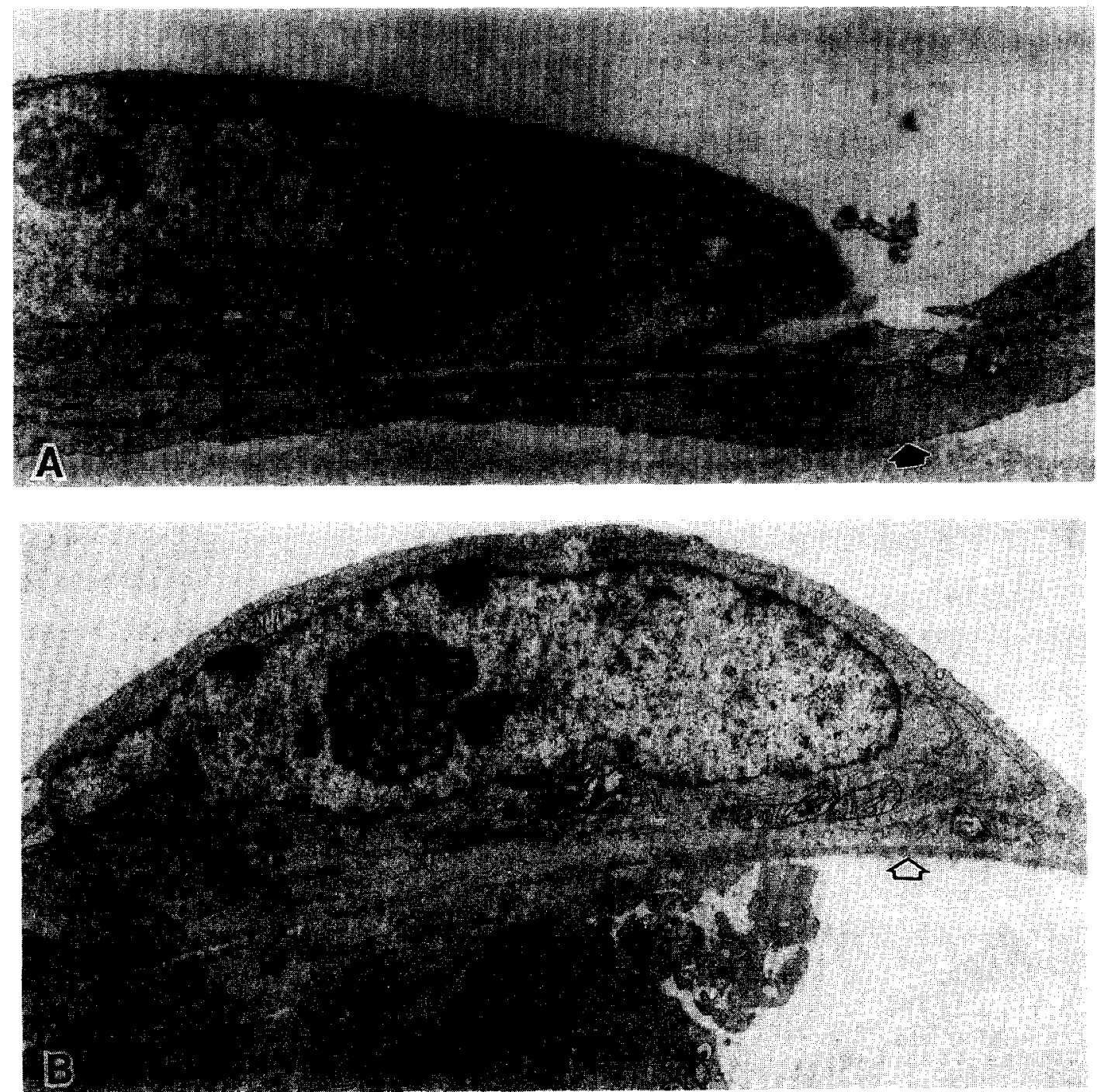

FIG. 5. Transmission electron microscopy of recovering adherent endothelial cells 30 and 60 min after removal of oligomycin and addition of glucose $(5.5 \mathrm{mM})$. Cells were inhibited metabolically for $120 \mathrm{~min}$ prior to the recovery period. (A) $30 \mathrm{~min}$ recovery $11,500 \times$ magnification. Note the presence of normal microfilaments along with the bundled aggregate of microfilaments (solid arrow). (B) 60 min recovery $11,500 \times$ magnification. A normal basal layer of microfilaments (open arrow) has returned to the cytoplasm. 
endothelial cells (demonstrated by fluorescence microscopy) is further confirmation of earlier observations in other cell types [3-5]. The ultrastructural changes in microfilament organization associated with inhibition of ATP synthesis appear to represent a side to side aggregation of microfilament segments. These changes are very similar (if not identical) to those seen in microfilament organization following hydrogen peroxide $\left(\mathrm{H}_{2} \mathrm{O}_{2}\right)$ injury where ATP levels fall secondary to $\mathrm{H}_{2} \mathrm{O}_{2}$-mediated inhibition of ATP synthesis $[7,8,13,17]$. Preliminary observations using a fluorometric assay [18] to evaluate the possibility that metabolically inhibited endothelial cells might generate superoxide anion $\left(\mathrm{O}_{2}^{-}\right)$or $\mathrm{H}_{2} \mathrm{O}_{2}$ were negative. Further work will be needed to fully rule out any involvement of oxidants in this type of model, however. The microfilament aggregation seen by electron microscopy may well represent an important part of any cell injury from whatever cause which is characterized by a significant decline in ATP levels. The aggregates may become useful ultrastructural markers of cellular injury in vivo, particularly in animal models of ischemic or inflammatory tissue injury.

There were only subtle changes in endothelial cell morphology accompanying the microfilament disruption associated with metabolic inhibition. It is unlikely that changes in morphology associated with microfilament disruption alone would produce gross changes in capillary permeability during an ischemic event. However, a transmembrane association between microfilaments and fibronectin, an extracellular matrix protein, has been demonstrated [19] and suggests that microfilaments play an important role in cell adherence to the basement membrane. Also in support of this concept is work demonstrating that metabolically inhibited endothelial cells lose their normal adherence properties [20].

Thus, the pathophysiologic significance of these observations may be that ischemic or ATP-depleted endothelial cells may be relatively less adherent and potentially could come off the basement membrane of an ischemic large or small vessel especially during reflow, resulting in exposure of basement membrane which would initiate platelet deposition and the associated inflammatory response [21]. Also, the exposed basement membrane would not be a very effective permeability barrier. It may be very important to develop ways to maintain or restore endothelial cell ATP levels as a means of preventing this type of problem from occurring in vivo during acute ischemia.

In conclusion, ATP depletion which occurs in a cellular model of acute ischemia is correlated with a reversible disruption of endothelial cell microfilament architecture. This may play an important role in endothelial cell dysfunction during acute ischemia in vivo.

\section{ACKNOWLEDGMENTS}

The authors thank Dr. David Amato from the Department of Biostatistics, School of Public Health of the University of Michigan, for his expert assistance with the statistical evaluation of the data. They also thank Jeanne Burger and Sue Stuth for their expert technical assistance and Stacy Wilkinson for the preparation of the manuscript. This work was supported in large part from a Veterans Administration Merit Review Grant to Dr. Hinshaw.

\section{REFERENCES}

1. Korn, E. D. Actin polymerization and its regulation by proteins from non-muscle cells. Physiol. Rev. 62(2): 672, 1982.

2. Bershadsky, A. D., and Gelfand, V. I. Role of ATP in the regulation of stability of cytoskeletal structures. Cell Biol. Int. Rep. 7(3): 173, 1983.

3. Bershadsky, A. D., Gelfand, V. I., Svitkina, T. M., and Tint, I. S. Destruction of microfilament bundles in mouse embryo fibroblasts treated with inhibitors of energy metabolism. Exp. Cell Res. 127: 421, 1980.

4. Sanger, J. W., Sanger, J. M., and Jockusch, B. M. Differential response of three types of actin filament bundles to depletion of cellular ATP levels. Eur. $J$. Cell Biol. 31: 197, 1983.

5. Bereiter-Hahn, J., Tillmann, U., and Voth, M. Interaction of metabolic inhibitors with actin fibrils. Cell Tissue Res. 238: 129, 1984.

6. Lehninger, A. L. Biochemistry, 2nd ed. New York: Worth Pub., 1975. Chap. 19, pp. 519-20.

7. Spragg, R. G., Hinshaw, D. B., Hyslop, P. A., 
Schraufstatter, I. U., and Cochrane, C. G. Alterations in adenosine triphosphate and energy charge in cultured endothelial and $\mathrm{P}_{388 \mathrm{D}_{1}}$ cells following oxidant injury. J. Clin. Invest. 76: 1471, 1985.

8. Hyslop, P. A., Hinshaw, D. B., Halsey, W. A., Jr., Schraufstatter, I. U., Sauerheber, R. D., Spragg, R. G., Jackson, J. H., and Cochrane, C. G. Mechanisms of oxidant-mediated cell injury: The glycolytic and mitochondrial pathways of ADP phosphorylation are major intracellular targets inactivated by hydrogen peroxide. J. Biol. Chem. 263: $1665,1988$.

9. Labarea, C., and Paigen, K. A simple, rapid, and sensitive DNA assay procedure. Anal. Biochem. 102: 344, 1980.

10. Stanley, P. E., and Williams, S. G. Use of the liquid scintillation spectrometer for determining adenosine triphosphate by the luciferase enzyme. Anal. Biochem. 29: 281, 1969.

11. Wulf, E., Deboren, A., Bantz, F. A., Faulstich, H., and Wieland, T. H. Fluorescent phallotoxin, a tool for the visualization of cellular actin. Proc. Natl. Acad. Sci. USA 76: 4498, 1979.

12. Howard, T. H., and Meyer, W. H. Chemotactic peptide modulation of actin assembly and locomotion in neutrophils. J. Cell Biol. 98: 1265, 1984.

13. Hinshaw, D. B., Sklar, L. A., Bohl, B., Schraufstatter, I. U., Hyslop, P. A., Rossi, M. W., Spragg, R. G., and Cochrane, C. G. Cytoskeletal and morphological impact of cellular oxidant injury. Amer. $J$. Pathol. 123: 454, 1986.
14. Wang, K., Feramisco, J. R., and Ash, J. F. Fluorescent localization of contractile proteins in tissue culture cells. In D. W. Frederiksen and L. W. Cunningham (Eds.), Methods in Enzymology. San Diego: Academic Press, 1982. Vol. 85, pp. 514-562.

15. Bickel, P. J., and Doksum, K. A. Mathematical Statistics: Basic Ideas and Selected Topics. Oakland, CA: Holden-Day, 1977. pp. 218, 219.

16. Gaudio, K. M., Stromski, M., Thulin, G., Ardito, T., Kashgarian, M., and Siegel, N. J. Postischemic hemodynamics and recovery of renal adenosine triphosphate. Amer. J. Physiol. 251(4): F603, 1986.

17. Hinshaw, D. B., Armstrong, B. C., and Hyslop, P. A. Microfilament disruption in oxidant injury. Fed. Proc. 46(4): 1152, 1987. [Abstract]

18. Hyslop, P. A., and Sklar, L. A. A quantitative fluorimetric assay for the determination of oxidant production of polymorphonuclear leukocytes: Its use in the simultaneous fluorimetric assay of cellular activation processes. Anal. Biochem. 141: 280, 1984.

19. Hynes, R. O., and Destree, A. T. Relationships between fibronectin (LETS protein) and actin. Cell 15: $875,1978$.

20. Lee, S. L., and Fanburg, B. L. Glycolytic activity and enhancement of serotonin uptake by endothelial cells exposed to hypoxia/anoxia. Circ. Res. 60: 653, 1987.

21. Jaffe, E. A. Physiologic functions of normal endothelial cells. Ann. N.Y. Acad. Sci. 454: 279, 1985. 